\title{
Helicobacter pylori infection, dementia and primary open-angle glaucoma: are they connected?
}

\author{
Fani Tsolaki ${ }^{1 *}$, Jannis Kountouras ${ }^{2}$, Fotios Topouzis ${ }^{3}$ and Magda Tsolaki ${ }^{4}$
}

\begin{abstract}
Background: The study aims to elucidate the putative association between various forms of dementia, including Alzheimer's disease, primary open-angle glaucoma and Helicobacter pylori (H.pylori) infection in all possible combinations.

Methods: We prospectively recruited for the study 156 patients, divided into a dementia group, a glaucoma group and two control groups. All patients were submitted to neuropsychological evaluation aiming to detect dementia, ophthalmological examination, aiming to detect glaucoma, and H.pylori diagnostic testing. The provided data were analyzed with the question of possible correlation between the aforementioned entities.

Results: Positive correlations were found between $\mathrm{Hp}$ infection and dementia, Hp infection and glaucoma, as well as between dementia and glaucoma.

Conclusions: The study confirmed the hypothesis that neurodegenerative diseases such as dementia and glaucoma are linked to each other and to H.pylori infection.
\end{abstract}

Keywords: Dementia, Primary open-angle glaucoma, Helicobacter pylori, Neurodegenerative disease

\section{Background}

Alzheimer's disease (AD), the main cause of dementia, affects more than 30 million people worldwide, with a rising tendency towards the number of 100 million patients estimated to suffer from the disease in the year $2050[1,2]$. Primary open angle glaucoma (POAG) is the second cause of blindness worldwide [3]. H. pylori is a common, Gram-negative bacterium found in the stomach. It has been shown to elicit an inflammatory response (gastritis) by altering stomach $\mathrm{pH}$, and by secreting proteases and VacA. It has also been implicated in the development of gastroduodenal ulcer, gastric cancer, MALT-lymphoma and colorectal cancer [4-8].

Neurodegenerative disorders are believed to be linked to each other as well as to H.pylori infection in terms of epidemiology and etiology [9-13]. However, various studies investigating the issue have concluded to contradictory results [14-16]. For this reason, aim of the current prospective study is to elucidate the putative association between Alzheimer's disease and other dementias (frontotemporal- dementia- FTD), dementia with Parkinson's

\footnotetext{
* Correspondence: ftagaraki@gmail.com

'Ophthalmology Department, Hippokrateion General Hospital, Thessaloniki, Greece

Full list of author information is available at the end of the article
}

disease-PD, Lewy body dementia-LB), primary open-angle glaucoma (POAG) and H.pylori infection in all possible combinations, based on a wide range of diagnostic procedures, that would set the diagnosis of each disorder with accuracy and beyond doubt.

\section{Methods}

The study was performed in compliance with the Helsinki Declaration and after the approval of the Ethics Committee of the Aristotle University of Thessaloniki. The patients, whose informed consent was obtained prior to the initiation of the study were divided in the following groups:

i. A group of patients with dementia (60 patients), which included patients with official diagnosis of $A D$ (36 patients), PD (9 patients), LB (9 patients), FTD (6 patients) [17-20].

ii. A group of patients with POAG (35 patients).

iii. A control group of 31 subjects found negative for dementia and glaucoma. They were used for the analysis of $\mathrm{Hp}$ infection incidence in patients with dementia and glaucoma. 
Table 1 Comparative data regarding age and gender between patients with dementia, glaucoma and the subjects of the 2 control groups

\begin{tabular}{|c|c|c|c|c|c|}
\hline & $\begin{array}{l}\text { Patients with dementia } \\
n=60\end{array}$ & $\begin{array}{l}\text { Patients with glaucoma } \\
\mathrm{n}=35\end{array}$ & $\begin{array}{l}\text { First control group } \\
n=31\end{array}$ & $\begin{array}{l}\text { Second control group } \\
(n=30)\end{array}$ & $\begin{array}{l}\text { Statistical } \\
\text { significance }\end{array}$ \\
\hline Age & $61.34 \pm 6.526$ & $62.18 \pm 5.04$ & $62.41 \pm 4.49$ & $61.48 \pm 2.8$ & $p>0,05$ \\
\hline Male patients & $28(46.66 \%)$ & $14(46.66 \%)$ & $14(45.16 \%)$ & $13(43.44 \%)$ & $p>0,05$ \\
\hline
\end{tabular}

The table shows comparative data in regard to age and gender between the patients with dementia, glaucoma and the patients of the two control groups. The comparison was performed with the non parametric Mann-Whitney-Wilcoxon test for the age analysis and the $x 2$ for the gender distribution. The level of statistical significance was set at a threshold for $\mathrm{p}<0.05$.

iv. A second control group of 30 subjects recruited from an emergency ophthalmology department, used for the analysis of correlation between dementia and glaucoma.

\section{Neuropsychological battery}

All participants were checked for dementia with the application of a neuropsychological battery consisting of the Mini Mental State Examination, the Functional Rating Scale for Symptoms of Delirium, the Neuropsychiatric Inventory, the Hindi Mental State Examination and the Geriatric Depression Scale [21-28].

\section{Ophthalmological examination}

The ocular examination was based on visual acquity control (reading of an optotype from a distance of 5 meters), tonometry with a Goldmann's applanation tonometer [29] after application of a local anesthetic (hydrochloric proxymetacaine $0.5 \%$ ), and fundoscopy after the application of tropicamide solution $0.5 \%$ and of the a-adrenergic stimulator phenylefrine in a solution of $5 \%$. The examination was concluded with a control of visual fields in a static perimetry apparatus type Octopus 900 (Haag-Streit, Switzerland).

Table 2 Helicobacter pylori infection in patients with dementia and control patients

\begin{tabular}{|c|c|c|c|c|}
\hline Dementia & $\begin{array}{l}\text { Percentage } \\
\text { in } \%\end{array}$ & $\begin{array}{l}\text { Control } \\
\text { group }\end{array}$ & $\begin{array}{l}\text { Percentage } \\
\text { in } \%\end{array}$ & $\begin{array}{l}\text { Statistical } \\
\text { significance }\end{array}$ \\
\hline $41 / 60$ & 68.33 & $14 / 31$ & 45.16 & $p<0.05$ \\
\hline $\begin{array}{l}\text { Alzheimer's } \\
\text { disease }\end{array}$ & 69.44 & $14 / 31$ & 45.16 & $p<0.05$ \\
\hline \multicolumn{5}{|l|}{$25 / 36$} \\
\hline $\begin{array}{l}\text { Parkinson's } \\
\text { dementia }\end{array}$ & 66.67 & $14 / 31$ & 45.16 & $p<0.05$ \\
\hline \multicolumn{5}{|l|}{$6 / 9$} \\
\hline $\begin{array}{l}\text { Frontotemporal } \\
\text { dementia }\end{array}$ & 66.67 & $15 / 31$ & 45.16 & $p<0.05$ \\
\hline \multicolumn{5}{|l|}{$4 / 6$} \\
\hline $\begin{array}{l}\text { Lewy body } \\
\text { dementia }\end{array}$ & 66.67 & $15 / 31$ & 45.16 & $p<0.05$ \\
\hline $6 / 9$ & & & & \\
\hline
\end{tabular}

The table depicts comparative data between patients with dementia in total and per diagnosis and members of the control group in regard to $\mathrm{Hp}$ infection. For the statistical analysis the $x 2$ criterion was applied. The level of statistical significance was set at a threshold for $\mathrm{p}<0.05$.
Diagnostic criteria for glaucoma were the ones provided by the Thessaloniki Eye Study [30].

\section{Helicobacter pylori infection diagnosis}

The examination for the $\mathrm{Hp}$ infection was based on gastroscopy and histological examination of the retrieved tissue specimens. Gastroscopy was performed after induction of sedation with midazolame (Dormicum) in an iv. administration and in a dosage of 3-5 mg, according to the patient's weight. This was followed by application of xylocaine to the nasopharynx in a spray form. The endoscopic instrument that was used for the research was an Olympus gastroscope.

Histological examination of the tissue specimens was based on a Cresyl-Violet staining. In a small number of patients (5), who couldn't be submitted to endoscopy due to lack of cooperation, we performed a serological examination of IgG antibodies against H.pylori.

\section{Statistical analysis}

The statistical analysis was based for the comparison of percentages on the $x^{2}$ criterion. For the quantitative parameters the analysis was based on the non parametric Mann-Whitney-Wilcoxon test. The quantitative parameters were expressed as mean \pm standard deviation. The levels for statistical significance were set for values of $\mathrm{p}<0.05$. The program we used for the statistical analysis was the SPSS $21.0 \mathrm{v}$.

\section{Results and discussion}

The study concluded to positive correlations between HP infection and dementia and H.pylori infection and glaucoma. This was expressed as an augmented frequency of H.pylori infection in the two groups in comparison to the

Table $3 \mathrm{Hp}$ infection in glaucoma and control group patients

\begin{tabular}{lllll}
\hline $\begin{array}{l}\text { Patients with } \\
\text { glaucoma }\end{array}$ & $\begin{array}{l}\text { Percentage } \\
\text { in } \%\end{array}$ & $\begin{array}{l}\text { Control } \\
\text { group }\end{array}$ & $\begin{array}{l}\text { Percentage } \\
\text { in } \%\end{array}$ & $\begin{array}{l}\text { Statistical } \\
\text { significance }\end{array}$ \\
\hline $24 / 35$ & $68.57 \%$ & $14 / 31$ & 45.16 & $p<0.05$ \\
\hline
\end{tabular}

The table shows comparative data between patients with glaucoma and subjects of the control group in regard to Hp infection. For the statistical analysis the $x 2$ criterion was applied. The level of statistical significance was set at a value for $p<0.05$. 
Table 4 Frequency of glaucoma in patients with dementia - frequency of glaucoma in patients of the control group

\begin{tabular}{|c|c|c|c|c|}
\hline Patients with dementia & Percentage in \% & Control group & Percentage in $\%$ & $\begin{array}{l}\text { Statistical } \\
\text { significance }\end{array}$ \\
\hline $10 / 60$ & 16.66 & $\begin{array}{l}\text { The control group had } \\
\text { no members with glaucoma }\end{array}$ & $\begin{array}{l}\text { The control group had } \\
\text { no members with glaucoma }\end{array}$ & $p<0.01$ \\
\hline
\end{tabular}

\section{Patients with Alzheimer's disease $\quad 19.44$}

$7 / 36$

Patients with Parkinson's dementia $\quad 33.33$

$3 / 9$

The table shows comparative data regarding the frequency of glaucoma in patients with dementia and control group. The control group had no members with glaucoma. For the statistical analysis the $x 2$ criterion was applied. The level of statistical significance was set at a value for $p<0.05$.

frequency of the control group $(68.33 \%$ in patients with dementia vs $45.16 \%, \mathrm{p}<0.05,68.57 \%$ in patients with glaucoma vs $45.16 \%, \mathrm{p}<0.05)$. It has also shown a positive correlation between dementia and glaucoma, both in the form of augmented frequency of glaucoma in patients with $\mathrm{AD}$ and $\mathrm{PD}(16.66 \%$ vs $0 \%$,) as well as in the form of augmented frequency of dementia (AD and FTD) in patients with glaucoma ( $16.66 \%$ vs $0 \%$ ), in comparison to the frequency in the control group. The aforementioned findings are depicted in Tables 1, 2, 3, 4 and 5.

The positive findings of the study in regard to the association of dementia (particularly AD) and Hp infection, POAG and H.pylori infection and finally, between dementia and POAG come to confirm the related conclusions reached by Kountouras et al. [9,11,12] and Bayer et al. [13].

Which common pathophysiological pathways stand behind the examined entities is not yet known. A possible explanation is that H.pylori infection initiates mechanisms of humoral and cellular immune response, which create crossreactions due to common genetic components with the ones found in nerve tissue; what follows are apoptosisrelated mechanisms of cell destruction which are frequent in neurodegenerative diseases, such as dementia and glaucoma [31].

Another theory that might explain the findings of the study is that of the augmented permeability of the

Table 5 Frequency of dementia in patients with glaucoma and control group

\begin{tabular}{lllll}
\hline $\begin{array}{l}\text { Patients with } \\
\text { glaucoma }\end{array}$ & $\begin{array}{l}\text { Percentage } \\
\text { in } \%\end{array}$ & $\begin{array}{l}\text { Control } \\
\text { group }\end{array}$ & $\begin{array}{l}\text { Percentage } \\
\text { in } \%\end{array}$ & $\begin{array}{l}\text { Statistical } \\
\text { significance }\end{array}$ \\
\hline $5 / 35$ (4 patients & 14.28 & The control & \\
with Alzheimer's & & group & \\
disease and 1 & & members & \\
with & had no & \\
Frontotemporal & & dementia & \\
Dementia) & & &
\end{tabular}

The table shows comparative data regarding the frequency of dementia in patients with glaucoma and control patients. The control group members had no dementia. For the statistical analysis the $x 2$ criterion was applied. The level of statistical significance was set at a value for $p<0.05$. blood-brain barrier in patients with neurodegenerative diseases, such as multiple sclerosis [32,33]; this phenomenon may give to the H.pylori the chance to enter the barrier and accelerate or influence their course. Similarly, Deretzi et al. have recently [34] proposed a theory that H.pylori or other pathogens may follow a distinct pathway to bypass the blood-brain barrier and cause damage to the brain. More specifically, they use the gastrointestinal tract (GIT) retrograde axonal transport through sensory or motor fibres in order to invade the central nervous system.

The findings of the study may have important practical applications for our patients in the future. They may lead to a widely accepted eradication of H.pylori as a measure for prevention against dementia and glaucoma. They also may lead to the establishment of routine diagnostic examinations for glaucoma in patients with dementia and of dementia in patients with glaucoma, which would influence the quality of life of these patients positively. Continued research in this field in the epidemiological, but more intensely in the molecular level, might further clarify common biochemical pathways linking dementia, glaucoma and $\mathrm{Hp}$ infection.

\section{Conclusions}

i. H.pylori infection is more frequent in patients suffering from $\mathrm{AD}$ and other forms of dementia than in the general population.

ii. H.pylori infection is more frequent in patients suffering from POAG than in the general population.

iii. POAG is more frequent in patients suffering from dementia (AD and $\mathrm{PD})$ than in the general population.

iv. Dementia (AD and FTD) is more frequent in patients with POAG than in the general population.

\section{Abbreviations}

AD: Alzheimer's disease; POAG: Primary open-angle glaucoma; Hp: Helicobacter pylori; PD: Dementia with Parkinson's disease; FTD: Frontotemporal dementia; LB: Lewy body dementia. 


\section{Competing interests}

The authors declare that they have no competing interests.

\section{Authors' contributions}

FT is the key author and was responsible for the recruitment of patients. JK assisted in the gathering of the material and supervised the study. FT assisted in the planning and supervised the study. MT assisted in the gathering of the material, supervised the study and corrected the paper. All authors read and approved the final manuscript.

\section{Author details}

'Ophthalmology Department, Hippokrateion General Hospital, Thessaloniki, Greece. ${ }^{2}$ Second Medical Department, Hippokrateion General Hospital, Aristotle University of Thessaloniki, Thessaloniki, Greece. ${ }^{3}$ Ophthalmology Department, Aristotle University of Thessaloniki, AHEPA Hospital, Thessaloniki, Greece. ${ }^{4} 3 \mathrm{~d}$ Department of Neurology, Aristotle University of Thessaloniki, Papanikolaou General Hospital, Thessaloniki, Greece.

\section{Received: 19 September 2014 Accepted: 19 February 2015} Published online: 11 March 2015

\section{References}

1. "Alzheimer" Association. 2012 Alzheimer's disease facts and figures. Alzheimers Dement. 2012;8(2):131-68.

2. Brookmeyer R, Johnson E, Ziegler-Graham K, MH Arrighi. Forecasting the global burden of Alzheimer's disease. Alzheimer's and Dementia. 2007;3(3):186-91

3. Resnikoff S, Pascolini D, Etya'ale D, Kocur I, Pararajasegaram R, Pokharel GP, et al. Global data on visual impairment 2002. Bull World Health Organ. 2004;82(11):844-51.

4. IARC Working Group on the Evaluation of Carcinogenic Risks to Humans. IARC monographs on the evaluation of carcinogenic risks to humans. Infection with Helicobacter pylori. Lyon, 7-14 June 1994. IARC Monogr Eval Carcinog Hum. 1994;61:1-241

5. International Agency for Research on Cancer. Schistosomes, liver flukes and Helicobacter pylori. Lyon, France. IARC Monogr Eval Carcinig Risks Hum. 1994;61:1-241

6. Kountouras J, Zavos C, Chatzopoulos D, Katsinelos P. New aspects of Helicobacter pylori infection involvement in gastric oncogenesis. J Surg Res. 2008;146:149-58.

7. Roesler BM, Rabelo-Gonçalves EM, Zeitune JM. Virulence Factors of Helicobacter pylori: A Review. Clin Med Insights Gastroenterol. 2014;7:9-17. 27.

8. Kountouras J, Zavos C, Chatzopoulos D, Katsinelos P. New aspects of Helicobacter pylori involvement in gastric oncogenesis. Surg Res. 2008;146(1):149-58

9. Kountouras J, Tsolaki M, Gavalas E, Boziki M, Zavos C, Karatzoglou P, et al. Relationship between Helicobacter pylori infection and Alzheimer disease. Neurology. 2006;66(6):938-40

10. Kountouras J, Boziki M, Gavalas E, Zavos C, Deretzi G, Chatzigeorgiou S, et al. Five-year survival after Helicobacter Pylori eradication in Alzheimer disease patients. Cogn Behav Neurol. 2010;23(3):199-204.

11. Kountouras J, Mylopoulos N, Boura P, Bessas C, Chatzopoulos D, Venizelos J, et al. Relationship between Helicobacter pylori infection and glaucoma. Ophthalmology. 2001;108(3):599-604.

12. Kountouras J, Mylopoulos N, Chatzopoulos D, Zavos C, Boura P, Konstas AG, et al. Eradication of Helicobacter pylori may be beneficial in the management of chronic open-angle glaucoma. Arch Intern Med. 2002;162(11):1237-44.

13. Bayer AU, Ferrari F, Erb C. High occurrence rate of glaucoma among patients with Alzheimer's disease. Eur Neurol. 2002;47(3):165-8.

14. Shiota S, Murakami A, Yoshiiwa K, Ohno S, Kuroda A, Mizukami K. The relationship between Helicobacter pylori infection and Alzheimer's disease in Japan. J Neurol. 2011;258(8):1460-3.

15. Kessing LV, Lopez AG, Andersen PK, Kessing SV. No increased risk of developing Alzheimer disease in patients with glaucoma. J Glaucoma. 2007;16(1):47-51.

16. Kurtz S, Regenbogen M, Goldiner I, Horowitz N, Moshkowitz M. No association between Helicobacter pylori infection or CagA-bearing strains and glaucoma. J Glaucoma. 2008;17(3):223-6.

17. McKhann G, Drachman D, Folstein M, Katzman R, Price D, Stadlan EM. Clinical diagnosis of Alzheimer's disease: report of the NINCDS-ADRDA Work
Group under the auspices of Department of Health and Human Services Task Force on Alzheimer's disease. Neurology. 1984;34(7):939-44.

18. Emre M, Aarsland D, Brown R, Burn DJ, Duyckaerts C, Mizuno Y, et al. Clinical diagnostic criteria for dementia associated with Parkinson's disease Mov Disord. 2007;22(12):1689-707.

19. McKeith IG, Galasko D, Kosaka K, Perry EK, Dickson DW, Hansen LA. Consensus guidelines for the clinical and pathological diagnosis of dementia with Lewy bodies (DLB): Report of the consortium on DLB international workshop. Neurology. 1996;1996(47):1113-24.

20. Neary D, Snowden JS, Gustafson L, Passant U, Stuss D, Black S, et al. Frontotemporal lobar degeneration: a consensus on clinical diagnostic criteria. Neurology. 1998;51(6):1546-54. Review.

21. Folstein MF, Folstein SE, McHugh PR. "Mini-mental state". A practical method for grading the cognitive state of patients for the clinician. J Psychiatr Res. 1975;12(3):189-98.

22. Fountoulakis KN, Kaprinis SG, Kaprinis GS. Special characteristics affecting the neuropsychologic assessment of the elderly in Greece. Am J Alzheimers Dis Other Demen. 2002;17(5):273-6.

23. Tsolaki M, Sakka V, Gerasimou G, Dimacopoulos N, Chatzizisi, Fountoulakis $\mathrm{KN}$, et al. Correlation of rCBF (SPECT), CSF tau, and cognitive function in patients with dementia of the Alzheimer's type, other types of dementia, and control subjects. Am J Alzheimers Dis Other Dement. 2001;16(1):21-31.

24. Connor DJ, Sabbagh MN, Cummings JL. Comment on administration and scoring of the Neuropsychiatric Inventory in clinical trials. Alzheimers Dement. 2008;6:390-4.

25. Cummings $J \mathrm{~L}$, Ihl R, Herrschaft $H$, Hoerr $R$, Tribanek M. Sensistivity to change of composite and frequency scores of the Neuropsychiatric Inventory of mild to moderate dementia. Int Psychogeriatr. 2013;25(3):431-8.

26. Yesavage JA, Brink TL, Rose TL, Lum O, Huang V, Dey $M$ et al. Development and validation of a geriatric depression scale: a preliminary report. J Psychiatr Res. 1982-1983:17(1):37-49.

27. Yesavage JA. Geriatric depression scale: consistency of depressive symptoms over time. Percept Mot Skills. 1991;73(3 Pt1):1032.

28. Ganguli M, Ratcliff G, Chandra S, Sharma S, Gillby J, Pandav R, et al. A hindi version of the MMSE: the development of a cognitive screening instrument for a largely illiterate rural elderly population in India. Int J Geriatr Psychiatr. 1995;10:367-37724.

29. Ehrlich JR, Radcliffe NM, Shimmvo M. Goldmann applanation tonometry compared with corneal-compensated intraocular pressure in the evaluation of primary open-angle Glaucoma. BMC Ophthalmol. 2012;12:52.

30. Topouzis F, Wilson MR, Harris A, Founti P, Yu F, Anastasopoulos E, et al. Risk factors for primary open-angle glaucoma and pseudoexfoliative glaucoma in the Thessaloniki Eye Study. Am J Ophthalmol. 2011;152(2):219-28.

31. Kountouras J, Gavalas E, Zavos C, Stergiopoulos C, Chatzopoulos D, Kapetanakis $\mathrm{N}$, et al. Alzheimer's disease and Helicobacter pylori infection: Defective immune regulation and apoptosis as proposed common links. Med Hypotheses. 2007;68(2):378-88.

32. Van de Haar HJ, Burgmans S, Hofman PA, Verhey FR, Jansen JF, et al. Blood-brain barrier impairment in dementia: Current and future in vivo assessments. Neurosci Biobehav Rev. 2014;49C:71-81.

33. Shimizu F, Kanda T. Disruption of blood-brain barrier in multiple sclerosis and neuromyelitis optica. Ihon Rinsho. 2014;72(11):1949-54. Article in Japanese.

34. Deretzi G, Kountouras J, Grigoriadis N, Zavos C, Chatzigeorgiou S, Koutlas E, et al. From the "little brain" gastrointestinal infection to the "big brain" neuroinflammation: a proposed fast axonal transport pathway involved in multiple sclerosis. Med Hypotheses. 2009;73(5):781-7. 